IRSH 55 (2010), pp. 38 I-4I 2 doi:I0.I0I7/S0020859010000398

(C) 2010 Internationaal Instituut voor Sociale Geschiedenis

\title{
The Brazilian and Italian Labor Courts: Comparative Notes*
}

\author{
FERNANDO Teixeira Da Silva \\ Department of History, State University of Campinas, \\ UNICAMP, São Paulo \\ E-mail: ftdsilva@gmail.com
}

Summary: This article compares the Brazilian Labor Court, created in 1939, and the Italian Magistratura del Lavoro, instituted in 1926 by the government of Mussolini, to "harmonize" the conflicts between labor and capital through judicial means. The text problematizes the Brazilian intellectual tradition which sees the Labor Court either as a typically national product or as the transcription of an international model. It demonstrates that current polemics are fixed within the ambit of the "national problem" such as it was formulated in the I930s. The approach adopted does not concentrate exclusively on the formal apparatus of juridical structure, but interrogates its functioning over time in different historical conjunctures. The main goal of the article is to understand the Labor Court as an institutional recourse historically appropriated by different subjects, in particular by workers, who gave the courts differentiated political meanings.

The Brazilian Labor Court is one of the most solid and long-lasting institutions of the corporatist arrangements created in the I930s as part of an extensive volume of measures designed to protect workers. Getúlio Vargas ascended to power in 1930 after leading the conspiratorial movement that defeated Washington Luís, the last president of the First Republic (I889-1930), and thereafter governed for fifteen consecutive years. The "revolutionaries of 1930" defended the line that class conflict ought to make way for harmony between workers and employers. Since I93 I, unions had been associated with the Ministry of Labor and defined as support agencies that collaborated with the public authorities. There were bans on political and ideological activities, any meaningful type of labor action in the workplace and, in any given city or county, only one labor union was allowed per sector or type of business. Rights had to be

\footnotetext{
* Translated by Sean Purdy, Department of History, Universidade de São Paulo. I would like to register special thanks to Michael Hall, Silvia Lara, Marcel van der Linden, Samuel Souza, Antonio Gino Negro, and Joseli Nunes for their comments on the previous versions.
} 
ensured through labor laws and official channels, creating an institutional framework that, for the most part, still remains intact today.

In the context of increasing political polarization, mobilizing thousands of workers, especially from I934 to I935, a generalized repression was unleashed by the Vargas government. The Estado Novo (New State, I937-I 945) was marked by a dictatorial government, ruled by an officially authorized constitution, and sustained by the armed forces. During this period, in which the government conducted an intense political propaganda campaign, repressed communism, and developed industry nationally, the workers' movement was strictly controlled. At the same time, the New State crowned the victory of corporate unionism, and on I May I943, after nearly a decade of intense legislative activity, the Consolidated Labor Laws (CLT) were instituted, regulating the work of several labor categories and arbitrating individual and collective disputes between workers and employers, with the exception of rural workers.

Oliveira Vianna, one of the principal architects of labor legislation during the first government of Gétulio Vargas (1930-1945), stated repeatedly in his writings from the I940s onward that Brazilian labor law was "not a work of copying" the Italian fascist model, but, "to the contrary, a planned work, executed and finished with Brazil in view". 'Around sixty years later, the title and subtitle of a book by the jurist Arion Sayão Romita, published in 200I, speaks volumes with respect to the longevity and persistence of the subject: "Fascism in Brazilian labor law: the influence of the Carta del Lavoro on Brazilian labor legislation". ${ }^{2}$ Both writers, in their own way, defended the existence of national pecularities: Vianna, in professing the originality of Brazilian corporatism, and Romita, in attributing to Italian fascism the registered mark of an exported corporatism.

The controversy has sparked revealing comparative research on labor legislation in the two countries, ${ }^{3}$ but as yet there have not been consistent efforts to compare specifically the Brazilian Labor Court (Justiça do Trabalho),

I. Oliveira Vianna, Problemas de direito sindical (Rio de Janeiro, I943), pp. xv-xvi. Oliveira Vianna (1883-I95 I) received his bachelor's degree from the Faculty of Law Rio de Janeiro, distinguished himself as a writer with a very vast sociological and juridical production, and was the most important author in the tradition of so-called Brazilian authoritarian thought. After 1930, he was a juridical consultant to the Ministry of Labor and one of the principle formulators of labor legislation.

2. Ario Sayão Romita, O fascismo no direito do trabalho brasileiro: influência da Carta del Lavoro sobre a legislação trabalhista brasileira (São Paulo, 200I). Romita was full professor in the Faculty of Law at the University of the State of Rio de Janeiro.

3. Michael McDonald Hall, "Corporativismo e fascismo nas origens das leis trabalhistas brasileiras”, in Ângela Araújo (ed.), Do corporativismo ao neoliberalismo: Estado e trabalhadores no Brasil e na Inglaterra (São Paulo, 2002), pp. I3-28; Mário Cléber Lanna Júnior, "Duas histórias de regulação do trabalho e do capital: um estudo comparado da legislação do Estado Novo brasileiro e do fascismo italiano" (unpublished Ph.D. thesis in history, Universidade Federal do Rio de Janeiro, 1999). 
created in $1939,{ }^{4}$ and the Italian Labor Court (Magistratura del Lavoro), instituted in 1926 by the government of Mussolini, to "harmonize" the conflicts between labor and capital through judicial means.'

More than making an inventory of the differences and similarities between these labor courts of varied origin, in this article I aim to problematize the Brazilian intellectual tradition which sees the Labor Court either as a typically national product or as the transcription of an international model. The experiences of other countries will help us to raise questions related to the "national case", to test hypotheses, and better interrogate the object of investigation. ${ }^{6}$ Comparisons that extend beyond the limits of national frontiers will provide the possibility for a more elaborated understanding of the choices that contributed to the organization of the Labor Court in the context of an international repertory of congeneric experiences. It is necessary as well to evaluate the weight and the significance of these choices in social, political, and juridical terms. This procedure also aims to overcome the "methodological nationalism" so prevalent in Brazilian academic activity which forestalls understandings of wider historical processes and their interactions. It is necessary to see relations between "national communities" as fluid, malleable, and exercising a mutual influence. ${ }^{7}$ Inasmuch as capitalist industrialization has historically utilized diverse juridical arrangements, we can attempt to identify the elements that the creators of labor law in Brazil absorbed from other national experiences as well as those that originated in Brazil. This text aims to contribute to this comparative endeavor.

This subject should not be reduced to historiographical polemics, but it is, however, eminently political. For those who today defend the thesis of the Brazilian authenticity of the Labor Court, it should maintain its principal characteristics since it has existed to defend the interests of workers. For those who judge the courts as a transplant from Italy, it is necessary to change them profoundly, eliminating their fascist roots or even extinguishing them, since their permanence has had anesthetic effects on the bargaining power of the working class. Contrary to what many hoped for, however, the Brazilian Labor Court achieved national notoriety in the 1980 s and the 1988 Constitution significantly extended its powers. In the I990s, there was an explosion of litigation in the country's tribunals, and recently there have been almost two million individual cases opened per year, giving Brazil the record as the country with the largest number of labor processes in the world. ${ }^{8}$

4. Law Decree n. I.237, 2 May I939.

5. Law n. 563, 3 April 1926.

6. Hall, "Corporativismo e fascismo", p. I9.

7. Marcel van der Linden, "Globalizando a historiografia das classes trabalhadoras e dos movimentos operários: alguns pensamentos preliminares”, Trajetos, I (2002), pp. 9-24.

8. Almir Pazzianotto Pinto, I00 anos de sindicalismo (São Paulo, 2007), p. 227. 
Without establishing a normative or propositional argument on the merits of the Labor Court, this article shows that current controversies remain fixed within the ambit of the "national problem" such as it was formulated in the I930s. In "freezing" the Labor Court at its moment of creation during the New State (1937-I945), a vast intellectual tradition has given it a fixed identity, sometimes as a genuine national construction and sometimes as an import from the fascist model, thus generalizing it for all its long history. As a result, what it represents today is deduced as its "original sin". The transplant thesis has traditionally dominated in the intellectual formation of this identity and already constitutes a part of Brazilian academic "common sense" regarding the importation of ideas and institutions "strange to our reality", since Brazilians are supposedly incapable of thinking about the "real situation" of the country. ${ }^{9}$ So it will be appropriate to dissect it in detail, aiming to undo the concatenation of concepts that confuse "fascism", "corporatism", "union structure", "labor legislation", and "labor court", attributing to them identical properties and political meanings.

The majority of studies of the Labor Court engage with its strictly legal and institutional aspects. In this approach, furthermore, the objectives of the Labor Court in demobilizing the working class were completely effective, absolutely subordinating workers to the structures of a class domination always undergirded by state control. ${ }^{10}$ For this reason, the analytic procedure adopted in this article does not exclusively concentrate on the formal apparatus of juridical structure. I will interrogate the courts' functioning over time. I will thus make some incursions into different conjunctures whose contextualization will be presented throughout the text so as to understand the courts as an institutional recourse historically appropriated by different subjects, in particular by workers, who gave them differentiated political meanings.

The two principal architects of the labor courts in Brazil and Italy, Oliveira Vianna and Alfredo Rocco respectively, ${ }^{\text {II }}$ shared four central points as to the new ordering of the world of work:

(I) The juridical recognition of trade unions under rigorous state control.

(2) The importance and efficiency of collective contracts.

9. Maria Stella Martins Bresciani, O charme da ciência e a sedução da objetividade: Oliveira Vianna entre os intérpretes do Brasil (São Paulo, 2005), pp. I I 5-1 I6.

Io. Sidney Chalhoub and Fernando Teixeira da Silva, "Sujeitos no imaginário acadêmico: escravos e trabalhadores na historiografia brasileira desde os anos 1980", Cadernos AEL, I4 (2009), pp. I I -47 .

I I. Alfredo Rocco (1875-1935) was Professor of Law at different Italian universities, joined a nationalist group at the beginning of the I9Ios, broke with liberal democracy in 19I4, and adhered to fascism in the I920s. In 1925 he was named Minister of Justice. His work was characterized by a strict association between nation, state, and society, emphasizing the role of the professional corporations as organizers of a corporatist state. As a strong man in the government, he became the principal architect of the fascist state; Saverino Battente, Alfredo Rocco: dal nazionalismo al fascismo, 1907-1935 (Milan, 2005). 
(3) The institution of the Labor Court.

(4) The extirpation of strikes and lock-outs. ${ }^{\mathrm{I} 2}$

The Labor Court was the fundamental part of this corporatist ordering and directly affected all the other aspects that Rocco and Vianna were concerned with.

The problem, however, is with the comparative practical effects derived from these general principles. For Aryon Romita, "the same phatic presuppositions and subjacent doctrine in Italy up to the creation of a specialized court were also present in Brazil when the creation of a Labor Court was considered here". ${ }^{\mathrm{I}}$ The Labor Court in Brazil was, then, entirely tributary of the Italian Labor Court in at least five aspects:

(I) Parity in representation before the courts (of employees, employers, and the state in its various instances).

(2) The principle of conciliation between the parties.

(3) A distinction between collective and individual bargaining.

(4) The special character of the labor courts inside the judicial power as a whole.

(5) Compulsory arbitration, and the normative power and equity of judicial decisions.

I will discuss each of these points in comparative perspective in order to then reflect on the "ghosts of corporatism" in Brazilian historiography. Finally, I will suggest other international influences on the development of labor law in Brazil beyond the Italian case.

\section{REPRESENTATIONAL PARITY}

One of the elements of approximation between the institutions in both countries would rest on the fact that "corporatism affirms itself definitively in the equal composition of the labor tribunals". ${ }^{\mathrm{I}}$ Before comparing Italy and Brazil in this respect, however, it is worthwhile underlining that such a classic representation scheme had already been practiced in the oldest of the labor courts, the Conseils de Prud'hommes in France, since the Revolution of I848. ${ }^{\text {I5 }}$ In the Weimar Republic (I919-1933) the courts at the first level were composed of a president and vice-president (magisterial judges), appointed by the justice administration of the state, and two lay judges

I2. These points are well formulated in ibid., p. 425 , and in Oliveira Vianna, Problemas de direito corporativo (Brasília, I983).

I 3. Arion Sayão Romita, "Justiça do Trabalho: produto do Estado Novo", in Dulce Pandolfi (ed.), Repensando o Estado Novo (Rio de Janeiro, 1999), pp. 95-I I 2, 98.

14. Romita, $O$ fascismo no direito do trabalho, p. 94.

I 5. Monique Kieffer, "La législation Prud'homale de I 806 à 1907", Le Mouvement Social, I4I (1987), pp. 9-23. 
representing employers and employed, with each one of these last representatives chosen by the president of the ordinary district court from a list of candidates prepared by the trade unions and employers' associations. ${ }^{16}$

A very similar practice was adopted in law by Brazil, but not in any way at all by fascist Italy. The Brazilian Commissions of Conciliation and Judgment (the court of first instance), with competence to settle individual conflicts, were to be presided over by a magistrate with the assistance of two "voters" (classist judges) nominated by the president of the Regional Council of Labor from names on organized lists chosen through election by the trade unions and employers' associations. The regional councils formed instances of appeal in relation to individual bargaining and arbitrated collective disputes, with the classist representatives indicated by the union and employers' associations and nominated by the President of the Republic. The highest organ was the National Council of Labor, equally paritary, with four representatives of employers and workers, chosen from triplicate lists by the Ministry of Labor. ${ }^{17}$

The Italian Labor Court, designed to deal with collective bargaining, consisted of a president and two counselors (three magisterial career judges), and associated with them, two "citizen experts" (cittadini esperti) on the problems of production and work, whose names were not scrutinized by the unions or professional associations. There was no parity of representation between bosses and workers: the experts were nominated by provincial councils of the economy according to the different productive sectors and companies existing in the district of the Appelates' Court, ${ }^{\mathrm{I} 8}$ and had to have obtained the Laurea Universitaria, or an equivalent title, not necessarily in law, which put them much closer to the interests of employers. One law from 1928, which created tribunals and praetorships to settle collective bargaining disputes, allowed that the judges be optionally assisted by two representatives from the parties in conflict, but in a merely consultative function, thereby rendering their actions less important. ${ }^{19}$

I6. Frieda Wunderlich, German Labor Courts (Chapel Hill, NC, I946), pp. 62-64; Benjamin Aaron, "The NLRB, Labor Courts, and Industrial Tribunals: a Selective Comparison", Industrial and Labor Review, 39 (1985), pp. 35-45, 36. We can also find conciliation and arbitration organs constituted by paritary representation in Mexico and Great Britain, among other countries; Mario de la Cueva, El nuevo derecho mexicano del trabajo (Mexico City, 1974); Erhard Blankenburg and Ralf Rogowski, "German Labour Courts and the British Industrial Tribunal System”, Journal of Law and Society, I 3 (1986), pp. 67-92, 84.

17. Araújo Castro, Justiça do Trabalho (Rio de Janeiro, I94I), pp. I04-I 21.

18. The names were submitted to the central corporatist organs or directly to the Appelate Court which forwarded them to the President of the Italian Labor Court, who did not have veto power; Lanna Júnior, Duas histórias de regulação do trabalho, pp. 203-205.

19. Gian Carlo Jocteau, La magistratura e $i$ conflitti di lavoro durante il fascismo, 1926-1934 (Milan, 1978), pp. 25, 42, 107-108. 
The laws that instituted judicial bodies in fascist Italy excluded the classist judges of the traditional labor tribunals. Before, the representatives of employers and employees, elected by their own unions and associations, composed the Collegi di Probiviri, created in I883 to conciliate and mediate individual conflicts. These were abolished by fascism in I928, above all through the pressure of industrialists who opposed any institutions with a paritary character. ${ }^{20}$ Therefore, corporatism, at least in its Italian version, was not composed with an equal and elected composition in its Labor Court. On the contrary: it eliminated them. Alfredo Rocco was adverse to any organization with a representative base and elective character which limited executive power. ${ }^{2 \mathrm{I}}$

In Brazil, a long debate ensued about the importance of the actions of the vogais (classist judges). For some authors, they had little weight in the decision-making process, merely approving the decisions of career judges and even voting against the interest of their own class, thereby undermining the paritary character of the Labor Court. ${ }^{22}$ More recently, the theme has been taken up in the context of a project of constitutional amendment, presented in 1992 by Hélio Bicudo, a Deputy of the Workers' Party, who proposed the extinction of paritary representation. In the process of constitutional revision in 1994 the debates intensified with the presentation of more than 20 amendments in this area, which ranged from the elimination to the maintenance of classist representation, and 870 proposals for relative amendments to the tribunals and to the labor judges in general.

Curiously, the principal defenders of the extinction of the vogais, such as the Central Única dos Trabalhadores (CUT), the main central left-wing trade union, and the majority of the magistrates of the Labor Court, did not raise arguments against the "corporatist" character of representation, but against the practices of nepotism and cooptation of union leaders, the high remuneration paid to lay judges, the absence of necessary juridical knowledge, the equalization of the classist judges to the status of formal judges, the anachronism of the institution, and the lack of impartiality. The lobby of the classist judges in the National Congress was also intense, aiming to convince politicians that their existence was fundamental to

20. Louis Rosenstock-Franc, L'économie corporative fasciste en doctrine et en fait (Paris, 1934), pp. 57, 179; Gian C. Jocteau, "L'ordinamento corporativo", in M. Antonioli et al. (eds), Storia del sindicato: dalle origini al corporativismo fascista (Venice, 1982), pp. 192-214, 210.

2. Jocteau, La magistratura e $i$ conflitti di lavoro, p. I43.

22. John French, Drowning in Laws: Labor Law and Brazilian Political Culture (Chapel Hill, NC [etc.], 2004), pp. 46-53; Kenneth S. Mericle, "Corporatist Control of the Working Class: Brazil", in James M. Malloy (ed.), Authoritarianism and Corporatism in Latin America (London, 1977), pp. 303-338, 3 I I-3 I 2; Antônio A. Silva, "Marcos legais do corporativismo no Brasil”, in Carlos A. de Oliveira et al. (eds), O mundo do trabalho (São Paulo, 1994), pp. 107-I32, I25. 
ensuring the democratization of the justice system, a system of brakes and counterweights to the decisions of formal judges, the class character of the tribunals, the celerity of processual rites, and the vocation of the Labor Court for conciliation. Only in 1999 was paritary representation abolished in the Senate by sixty-four votes to six. ${ }^{23}$

In any case, the tripartite and paritary structure in Brazil became a legally consecrated institution with formal and functional characteristics quite differentiated from that of the Labor Court in Italy. Indeed, Brazilian authors were aware of this model even before corporatism began to be implanted in Italy. In I919, the jurist Viveiros de Castro already defended the existence of "industrial councils", "composed of members elected by the bosses and by the workers, under the presidency of a representative of the government". ${ }^{24}$ We can suppose still that Viveiros de Castro knew the then existing ideas in the Italian "juridical environment", just as Rocco could have systematized and elaborated his proposals from the experiences and debates which were already circulating in international judicial circles.

\section{CONCILIATION OF INDIVIDUAL BARGAINING DISPUTES}

In 1938, the Brazilian jurist Theotonio Monteiro de Barros Filho affirmed that the "the corporatist regime makes implicit the ideas of conciliation and arbitration". ${ }^{25}$ Without doubt, these ideas served the collaborationist intentions of the Italian and Brazilian corporatists. However, the attempt at conciliation was and had been compulsory in diverse countries, conforming to a juridical principle widely implemented in international labor legislation. ${ }^{26}$ Conciliation en masse is a much older invention, which can be found in the French Conseils de Prud'homes, in which initially almost all cases were covered, a tendency which consolidated itself at least by the I 930 . $^{27}$

23. Pedro B. Vieira, Importância da representação paritária na Justiça do Trabalho (São Paulo, I993); Túlio V. Barreto, "O debate recente acerca da representação classista na Justiça do Trabalho", Cadernos de Estudos Sociais, I I (1995), pp. I77-197; Eli A. Silva, Representação classista na Justiça do Trabalho, July 1998, http://www.elialvesdasilva.adv.br/artigo2.html, last accessed I4 April 2010; Ives Gandra da Silva Martins, "A Justiça do Trabalho do ano 2000", Revista Juridica Virtual, 8 January 2000, http://www.planalto.gov.br/ccivil/revista/rev_08/ arg_descump_Juliano.htm, last accessed I4 April 20 го; CCJ aprova fim dos juízes classistas, I 4 April 1999, http://www.direito2.com.br/asen/ı999/abr/I4/ccj-aprova-fim-dos-juizes-classistas, last accessed I4 April 20 IO.

24. Augusto Viveiros de Castro, A questão social (Rio de Janeiro, I920), p. I2 I.

25. Cited in Romita, O fascismo no direito do trabalho, p. 94.

26. Samuel Fernando de Souza, “'Coagidos ou subornados': trabalhadores, sindicatos, Estado e as leis do trabalho nos anos 1930" (unpublished Ph.D. thesis, Universidade Estadual de Campinas, 2007), p. 59.

27. Alain Cottereau, "Cent quatre-vingts années d'activité prud'homale", Le Mouvement Social, I4I (1987), pp. 3-8, 6-8. 
The interaction of French workers and unions with the labor courts led to the forging, according to Phillippe Couton, of an historic "culture of conciliation", ${ }^{28}$ without having arrived at any rigorously corporatist experience. In France, they even spoke of a "juridical unionism" to denominate the strong involvement of the workers' movement with the Conseils. ${ }^{29}$ In the Weimar Republic, the rates of conciliation between the disputing parties was quite high and continued to be after the end of the Third Reich. ${ }^{30}$ Even in countries such as the United States and Britain, which could be considered the "ideal types" of an "anti-legal culture", that is, intractable to the regulation of work relations, adopted in their own ways mechanisms that sought agreements between parties in the courts. $^{3 \mathrm{I}}$

It is easy to search aimlessly and collect apparently similar specimens that belong, however, to very different national experiences. The most important point to underline is that, paradoxically, the conciliation practiced in the Italian corporatist organs was one of the principal causes of the weak performance of the Labor Court. How can we understand this paradox if one of the principal objectives of judicial organs was to conciliate the interests in a dispute? To understand the question it is necessary to clarify that the first step on the road to conflict resolution was the attempt at conciliation between unions and employers' representatives.

The agreements promoted by the unions, in general, led to workers renouncing many of their rights. Weakened by attempts at agreement within the ambit of the company, the union would denounce the company to the association of employers and form an arbitration commission. In this way, the union movement became the privileged site of a myriad of controversies. The individual disputes, conducted after the failure of conciliation in the praetorships and special tribunals, which were annexed to the ordinary magistrature (Appelates' Court), ${ }^{32}$ oscillated between 5 per cent and 20 per cent of the denunciations, and a little more than half

28. Philippe Couton, "A Labor of Laws: Courts and the Mobilization of French Workers", Politics E Society, 32 (2004), pp. 327-365.

29. Laurent Willemez, Le Droit du Travail en danger: une ressource collective pour des combats individuels (Broissieux, 2006).

30. From I90 I to I9I 8 , in the period before "corporatist conciliation", around 40 per cent of the cases brought to the industrial tribunals ended in conciliation; Wunderlich, German Labor Courts, p. 33. In the I970s, 30-40 per cent of the cases brought before the court of first instance were conciliated; Thilo Ramm, "Labor Courts and Grievance Settlement in West Germany", in Benjamin Aaron (ed.), Labor Courts and Grievance Settlement in Western Europe (Los Angeles, CA [etc.] i97I), p. I 17.

31. Aaron, "The NLRB", p. 40; Blankenburg and Rogowski, "German Labour Courts", p. 70. 32. The pretories dealt with cases that involved up to 5,000 lira while the tribunals had competency to deal with cases involving a greater value. Both formed a section together with the Appelates' Court. 
were concluded without a judicial sentence. ${ }^{33}$ To be more precise, in I932, 80,444 conflicts were communicated to the unions, which were conciliated in 5I,4I4 cases, with only 2,8 I9 cases arbitrated by the magistrates. ${ }^{34}$

Far from concluding that the unions were strong in their defense of the workers' interests, it is enough to keep in mind that they were strictly subordinated to the maxims of the fascist government and party. Moreover, in Italy a great number of conciliation bodies were created, with superimposed competencies, such as the Provincial Council of the Economy, under the presidency of the mayors, and the provincial interunion committees, which dealt with disputes of greater political and monetary relevance, making the tribunals practically inoperative.

In Brazil, on the contrary, the unions would never have shouldered the responsibility of obligatory conciliation of individual disputes before and outside the judicial arena. Such an attribution had always been an extenuating function of the Labor Court. This is an element which clearly differentiates the Brazilian Labor Courts, where all the conciliation activity of the individual disputes occurred in the Councils of Conciliation and Judgment, in the Regional Tribunals, and in the Supreme Labor Tribunal. ${ }^{35}$ Likewise, in some periods, such as in 1947 , the number of arbitrated processes was rather higher than the conciliated processes. Out of a total of 67,273 complaints in the 54 councils, I 8,543 were conciliated and 28,925 were arbitrated. ${ }^{36}$ Furthermore, the efficacy of the conciliation of conflicts in the juridical arena as an uncontested mechanism of class collaboration is quite questionable, according to the principles conceived by corporatism. In the daily practice of the tribunals, conciliation did not achieve the desired "social peace", and opened itself to numerous conflicts that were not limited to the dispute for "economic advantage", since they involved equally notions of personal honor, professional dignity, and class solidarity. ${ }^{37}$

In addition, the volume of conciliated cases and the workers' access to juridical services could depend less on the corporatist structure of the tribunals and more on the degree of formality of the processual rites and the quantity of disputes judged, as well as on the possibilities of the workers' success with a particular set of demands. In Germany, as in Brazil and France, the laws were more oriented to the resolution of individual rather

33. Jocteau, La magistratura e i conffitti, pp. I30-I33, I44-I45, I49-I I.

34. Rosenstock-Franc, L'économie corporative, p. I87.

35. After the 1946 Charter, both the tribunals, organs of second instance, substituted the Regional Counsel of Labor and the National Counsel of Labor.

36. Revista do TST, 2 ( 1948 ) cited in Edinaldo Oliveira Souza, "Bastidores da disputa trabalhista em comarcas do interior (Recôncavo Sul, BA, I940-1960)", História Social, is (2009), pp. 197-217.

37. Ibid.; Souza, "'Coagidos ou subornados"”. 
than collective disputes, and enjoyed solidly constructed and traditional conciliation procedures; in Britain, on the other hand, the judicial structure was much more formalist and, therefore, restrictive to the workers. ${ }^{38}$

\section{COLLECTIVE BARGAINING}

Was the distinction between juridical conflicts (individual) and economic conflicts (collective) really introduced in Brazil on the same terms adopted by Italian jurists? Such a distinction was present in other systems and was known by Brazilian legislators and jurists even before the creation of the Labor Court at the end of the 1930s. ${ }^{39}$ The Weimar Republic, for example, legally distinguished the so-called disputes of "interest" (individual) and of "rights" (collective), ${ }^{40}$ judged, as in Brazil, by differentiated instances. However, the Italian justice system presented a different model from the Brazilian in that, as already mentioned, collective bargaining was the responsibility of the Labor Court while individual disputes were subordinated to the praetorships and the lesser tribunals. ${ }^{4}$

More than differentiating the nature of the disputes themselves, the procedures adopted in the collective processes is what should be at the center of discussion. In Italy, disputes could only be forwarded to the Labor Court after all efforts at conciliation had been exhausted on the part of, first, the Federation and Confederation of Workers and, then, of the union..$^{42}$ As a result, the recourse to judicial means was the last possible chance at mediation between the parties, even though it represented a central role in collective agreements aiming, above all, at the containment of the strike option. In Brazil, the objective of recourse to the tribunals was the same, even though the initiative fell to the unions, and not the federations and confederations, except in sporadic cases. The essential difference between the two national cases is in the functioning of the justice system, but the analysis must also take into account other time periods that were not marked by the presence of dictatorial regimes. This is the crux of the analytical question: to overcome the formal limits of the juridical structure.

Between 1926 and 1937, there were only forty-one collective disputes that were considered by the Italian Labor Court, of which twenty-two were conciliated, three abandoned, and only sixteen concluded with a judicial sentence. ${ }^{43}$ Disputes related to the application or violation of contracts were atomized in a myriad of individual dissensions. The reason

38. Blankenburg and Rogowski, "German Labour Courts”, p. 70.

39. Castro, Justiça do Trabalho, p. 40.

40. Ramm, "Labor Courts", p. 86.

4I. Romita, A Justiça do Trabalho, p. 97.

42. Rosenstock-Franc, L'économie corporative, p. 57.

43. Jocteau, L'ordinamento corporativo, pp. 204-205. 
for the poor functioning of the Italian Labor Court is linked to the fact that Italian fascism did not admit, under any hypothesis, class conflicts, which had supposedly been overcome by the new corporatist order. Consequently, the party and the executive, through the provincial councils, through the discretionary action of the Ministry of Corporations and, above all, through the Public Ministry, preferred to interfere in such disputes, sidestepping the judicial arena. The Public Ministry was one of the principal instruments for the intervention of the executive power in the functioning of fascist labor courts. In Brazil, on the contrary, a Public Ministry of Labor was created, with its own jurisdiction, and therefore it was not subordinated to the executive and the common justice. ${ }^{44}$

The Italian Labor Court became, therefore, an extension of the wage policies of the regime. Despite this, its very existence revealed it as an inappropriate organ in a regime in which class conflict tended to be masked and avoided. Mussolini himself warned that recourse to the Labor Court should not become a habitual practice, avoiding to the maximum the actions of the career judges. ${ }^{45}$ The fascist regimes were, in fact, quite committed to the abolition of the jurisdiction of labor courts in collective bargaining and other conflicts, such as happened in the German Third Reich, which preserved judicial competence only in individual disputes. ${ }^{46}$

Despite the territorial and populational differences between Brazil and Italy, the Brazilian Labor Court was far from inoperative in collective disputes - quite contrary to what occurred in fascist Italy. Between the I940S and I970s, the Regional Tribunal of Labor of the Second Region, with headquarters in São Paulo, alone deliberated on more than 20,000 labor processes arising from collective disputes. From May i94 I to December 1949, the 8 regional tribunals of the country resolved I,232 collective disputes: 573 were conciliated, 229 were judged in favor of the unions, 178 were judged partially in favor of the unions and Io9 in favor of the employer. ${ }^{47}$ Thus, the effectiveness of labor rights could depend less on the institutional design of the labor laws and more on the actual political regimes, a topic which I will treat later in this article.

\section{SPECIAL JUSTICE}

Rocco criticized countries that adopted compulsory arbitration, justifying his position by declaring that the arbiter should not be a judge, since for an order to be authorized it was necessary to intrude on the parties, through an impartial organ capable of "giving reason to those who have it". For him,

44. Lanna Júnior, Duas histórias de regulação do trabalho, p. 201.

45. Jocteau, La magistratura e i conflitti di lavoro, pp. 46, 99.

46. Ramm, "Labor Courts", pp. 86-87.

47. Geraldo B. de Menezes, Dissídios coletivos do trabalho (Rio de Janeiro, 1950), p. 203. 
therefore, it was not necessary to appeal to a "special judgment", with a tripartite and paritary character, but simply to an ordinary magistrate, accustomed to taking decisions and judging independently of the executive power, far from political pressures. At the same time, Rocco was moved by the desire to make everything gravitate around the state, and the problem resided in the fact that decisions in the field of labor relations had economic and political implications which put at risk the fiction of the impartiality of the magistrature.

The solution was to trust in the labor jurisdiction of the Court of Appellation in such a way as to avoid the creation of a properly special justice such as the Collegi di Probiviri, which, according to Saverino Battente, put the system in crisis. ${ }^{8}$ Thus, the essentially "special" character of the Italian Labor Court, which was repeatedly conferred on it, had to be adjusted, as is shown by the strenuous efforts to integrate it in the ordinary magistrature. By the way, an Italian jurist mentioned in 1934 that the question was polemical with no "dominant opinion" among diverse authors. ${ }^{49}$ As a result, in harnessing the adjudicate organs to the appellate tribunals, Italian fascism opted for a compromise between special and ordinary jurisdiction, in such a way as to guarantee a form of political and hierarchical control over the Labor Court. ${ }^{50}$

The Brazilian Labor Court was neither original nor organically linked to the common justice, as in Italy. Already in the lacunal Article I 39 of the 1937 Charter, it was determined that the Labor Court "does not apply to the dispositions of this Constitution relative to the competence, recruitment and prerogatives of the common justice". It is common to affirm that it was conceived of as an organ of executive power, a sector of the Ministry of Labor. ${ }^{\text {I }}$ However, one of the justifications in 1938 of the commission that elaborated the organic legislation of the Labor Court clarified that it was intended "that the National Tribunal of Labor would assume a function that until now has been exercised by the Ministry of Labor". 52 Indeed, Law Decree I.237 of 1939, which instituted the Brazilian Labor Court, dispensed with any administrative character included in previous laws that regulated adjudicatory organs before the institutionalization of the Labor Court. The General Counsel of the Republic considered this to be "a justice system coordinated with the Ministry of Labor". ${ }^{53}$

The Labor Court would be formally constituted as a special organ since the execution of its judgments was to be the task of its own tribunals, with

48. Battente, Alfredo Rocco, p. 430.

49. Alessandro Raselli, La Magistratura del Lavoro: giurisdizione ed azione (Padua, 1934), p. 48.

50. Jocteau, La magistratura, pp. 362-365.

5. Romita, $O$ fascismo no direito do trabalho brasileiro, p. 102.

52. Castro, Justiça do Trabalho, p. 67.

53. Ibid., p. 80. 
the Federal Supreme Court still recognizing the judicial character of the labor courts. ${ }^{54}$ The Labor Court would be formally incorporated into the judicial power in 1946, but only as an autonomous and special part of the justice system. According to a study by Salete Maccaloz, the passage of the Labor Court to judicial power endowed it with "relative independence", without "political programs to achieve".55 In the period between the end of the New State (1945) and the military-civil coup of 1964, when it was possible for corporatist and democratic institutions to coexist under the strong growth of the workers' movement, the Labor Court was able to gain its own independent life.

It is appropriate here to conclude that the organization of the Italian Labor Court was more simplified: the appellate courts in each region were their own unique organs and the local public administration exercised a great influence on them. In Brazil, however, the hierarchical separation between commissions, regional councils, and the National Council of Labor indicates a greater centralization of the justice system at the federal level. ${ }^{56}$

\section{COMPULSORY ARBITRATION, NORMATIVE POWER, AND EQUITY}

"Substitute as much as possible the strike and the 'lock-out': this is the first function of the Labor Court". These words, which could have come from the pen of any Italian magistrate, were written a few years after the installation of the Brazilian Labor Court in the middle of the Estado Novo (1937-1945) by the Brazilian jurist Dorval Lacerda, ${ }^{57}$ one of the originators of the Consolidation of Labor Laws (CLT) in $1943 .{ }^{58}$ And the best instrument for such substitution should be, according to Lacerda, the "collective sentence" in the form of compulsory arbitration. When the parties could not arrive at an agreement, the unions had the prerogative to initiate disputes in the regional tribunals of labor in order to resolve collective agreements. In the case of strikes, such a prerogative was assumed by the President of the Court or of the Procuracy of the Labor Court. The judicial sentence had to have a normative character, that is, it

54. Orlando Gomes e Élson Felix Gottschalk, Curso de direito do trabalho (São Paulo, I97ı), p. 25 .

55. Salete Maria Maccalóz, Representação classista na Justiça do Trabalho (Rio de Janeiro, 1984), p. 88.

56. Lanna Júnior, Duas histórias de regulação do trabalho, p. $20 \mathrm{I}-202$.

57. Dorval Lacerda, "Sentença Coletiva", Boletim do Ministério do Trabalho, Induistria e Comércio, I35 (1945), pp. 95-96, 95.

58. On May Day I943, after a decade of intense legislative action, the Consolidation of Labor Laws (CLT) was presented to the workers as a "gift" of Getúlio Vargas. It was boasted as the most advanced social legislation in the world, regulating in its 922 articles the work of various professional categories. 
had to have the power to create norms and stipulate working conditions according to the collective agreements. As a result, one could say that in the case of the Brazilian Labor Court "the judge creates the law". 59 Such power was explicitly regulated by the Charter of 1946 which was unequivocally extended to all workers in a category or productive sector, independent of their unionization. Before 1946, however, the Consolidation of the Laws of Labor did not confer on the unions the competency to implement a collective agreement as a legal representative of each category, but only to those unionized, another difference from Italian law. ${ }^{60}$

It is difficult to deny that the original source of normative power was state-instituted compulsory arbitration from the beginning of the twentieth century in Australia and New Zealand, whose model was known by jurists in Brazil well before 1930. Based on a wide citation of sources, Viveiros de Castro, for example, discussed conciliation organs and arbitration in more than a dozen countries, lingering on the examination of Australia and New Zealand. ${ }^{61}$ In the opinion of Orlando Gomes and Elson Gottschalk,

[...] compulsory arbitration of collective conflicts did not originate, as is erroneously supposed, in the Labor Court of Fascist Italy; already in 1904, in Australia and New Zealand, [compulsory arbitration] was practiced through industrial tribunals with an administrative as much as a judicial nature, since they pronounced arbitration awards with the efficacy of a sentence. ${ }^{62}$

The Australian system, according to Raymond Markey, was "original in various aspects". For this reason, it is worthwhile briefly introducing the Australian system, above all because many other countries, such as Brazil (perhaps even Italy) were inspired by it. First, the central objective of compulsory arbitration, well before fascist corporatism, was more to reduce or annul the incidence of labor conflicts and less to regulate the collective agreements. ${ }^{63}$ Second, the interference of the state was amply involved - with the conciliation and arbitration commissions headed by judges of the Supreme Court. Third, the sentences pronounced by such commissions had the force of law. Agreements reached by collective contracts were "certified" by tribunals and gained the status of a sentence.

59. Délio Maranhão, "Processo de Trabalho", Arnaldo Sussekind, Délio Maranhão and Segadas Vianna, Instituiçôes de direito do trabalho (São Paulo, 199i), II, p. I 197.

60. Egon Felix Gottschalk, Norma pública e privada no direito do trabalho (São Paulo, 1944), p. 359 .

6r. Castro, A questão social, pp. I48-163.

62. Gomes and Gottschalk, Curso de direito do trabalho.

63. Also at the beginning of the twentieth century, reformist governments in Canada legislated arbitration and conciliation systems in order to end class conflicts; Dale Gibson, "Collective Labour Law in Canadá 18 12-1892", on Marcel van der Linden and Richard Price (eds), The Rise and Development of Collective Labour Law (Berne, 2000), pp. 97-139. 
Fourth, collective conflicts could be channeled to the tribunals by just one of the parties, with the other being obliged to participate in the judicial process. The sentence had to be obeyed by both parties, under the risk of sanctions. Fifth, the workers individually could only be represented by "registered unions", whose rules of functioning had to be examined by an industrial registrar. ${ }^{64}$

Later, other countries, whether they were corporatist or not, would adopt important parts of the Australian model of compulsory arbitration. In considering this experience as early as I919, Viveiros de Castro warned that the special labor tribunals "should be obligatory not only for the parties in conflict, as also for all those interested in the same sector of industry". 65

Perhaps most surprising is to recognize that the institution of compulsory state arbitration in Australia was not a work of "bourgeois reformists", but was designed and defended enthusiastically by the Australian Labor Party, with the support and manifest enthusiasm of the majority of the workers' movement. As Markey concludes, "state arbitration created its own clients among unions and employers' associations. Largely as a result of this, it survived intact for almost a century" ${ }^{66}$ (Perhaps this helps us better understand the longevity of the Brazilian Labor Court).

The normative power of the collective conventions was also anticipated in other countries, such as Weimar Germany, Mexico, Belgium, Portugal, and New Zealand. Perhaps Oliveira Vianna was right in affirming that there was no necessary relation between normative competence and a corporatist regime. ${ }^{67}$ Finally, in place of voluntary collective agreements, without the force of law, the idea of a legal apparatus capable of arbitrating conflicts was an invention of the end of the nineteenth century, well before the typically corporatist judicial systems. ${ }^{68}$

To sum up, related to the question of equity in the judgment of disputes, the law that governed collective contracts in Italy determined that the Labor Court should judge, "to establish the new conditions of work, according to equity, searching to conciliate the interests of the employers with those of the workers and defending in all cases the superior interests of production" ${ }^{69}$ In this case, without a doubt, the terms adopted in Brazil regarding this subject were, it seems, clearly inspired by Italian

64. Raymond Markey, "The Development of Collective Labour Law in Australia, I788-1914", Van der Linden and Price, The Rise and Development of Collective Labour Law, pp. 43-77.

65. Castro, A questão social, p. I48.

66. Markey, "The Development of Collective Labour Law in Australia", p. 77.

67. Vianna, Problemas de direito corporativo, pp. 78-85. In France, the prud'bomme, through their jurisprudence, also created laws; Kieffer, "La Législation Prud'homale", p. 20.

68. Marcel van der Linden and Richard Price, "Introduction", in Van der Linden and Price, Rise and Development of Collective Labour Law, pp. 7-18, I 2.

69. Alfonso, Construire lo Stato Forte, p. I99. 
legislators. According to Law Decree I.237 of 1939, which regulated the Labor Court, equity is the precept that harmonizes "the interests of the litigants with those of the collective, in such a way that no class or particular interest prevails over the public interest". Consequently, as much in Brazil as in Italy, the fixed nature of the juridical rules were attenuated in the name of an agreement between the parties and, above all, of "the superior interests of production", or, more generically in Brazil, of the "public interest".

Under the sacred mantle of "national interest", the sentences in Italy suffered the crushing weight of the executive power. The contractual activity of the Italian Labor Court closely followed the wage policies of the regime, with the productivist principle of juridical-economic nationalism predominating, as extolled by Rocco, and not the distributive principle. ${ }^{70}$ Paulo Ungari goes much further: Italian fascism did not possess an authentic labor court, but "a government instrument aiming to control a labor market in tune with the political economy". ${ }^{\text {I }}$ Collective contracts were obligatory and extensive for all the members of a category of workers, and had to be approved by the government. There were many limits placed on "contractual liberty", and the obligation to judge according to the "superior interests of production" redounded in repeated salary reductions for workers in the I920s and I930s, with the collaboration of the proper union leaders, under the pressure of industrialists, evidently with the guarantee of the fascist government. ${ }^{72}$

Without doubt, the normative character of the Labor Court in Brazil was heavily influenced by Italian legislators, and this should not be disregarded. The whole problem, nevertheless, resides in the deductions made from this observation, and in the weight that is given to Brazilian corporatism throughout the history of labor relations in Brazil beginning with the New State, as if the corporatist project had been unique, linear, and effectively implemented in its entirety. ${ }^{73}$ One cannot conclude, abruptly and mechanically, that the Labor Court in Brazil was molded according to the Italian model, without considering the differences in the functioning of this institution in diverse political contexts. It is sufficient to remember that the Brazilian corporatist arrangement survived the dictatorship that gave it life, to the contrary of what occurred in Italy, Spain, and Portugal. ${ }^{74}$ In relation to the importance of similarities and

70. Battente, Alfredo Rocco, p. 424.

71. Paolo Ungari, Alfredo Rocco e l'ideologia giuridica del fascismo (Brescia, 1974), p. 94.

72. Ibid., p. 200; Rosenstock-Franck, L'économie corporative fasciste, pp. I80-I 8 I, 200.

73. Adalberto Moreira Cardoso, "Direito do trabalho e relações de classe no Brasil contemporâneo", in Luiz Werneck Vianna (ed.), A democracia e os três poderes no Brasil (Rio de Janeiro, 2002), pp. 494-555, 498.

74. Michael M. Hall, "Labor and the Law in Brazil", in Van der Linden and Price, Rise and Development of Collective Labour Law, pp. 79-95, 79. 
eventual inspirations, the comparison cannot be limited to the "ghosts of the New State", to which we still remain bound. ${ }^{75}$

Aryon Romita affirms that "the passage of time does not mean anything for the Labor Court". ${ }^{6}$ With the sole (but no less important) argument that the normative power was not congruent with the democratic order installed by the Constitution of 1946, this author constructs a long bridge that binds the Estado Novo to the military dictatorship (1964-1984), passing through twenty years of intense activity by the Labor Court in collective disputes. Yet it is necessary for us to dismantle this "fixed identity" of the Labor Court that scholars have generalized to cover the many decades of the existence of the institution.

Between 1945 and 1964, the so-called Populist Republic was characterized by an unstable balance of alliances among unequal social class and political forces, within a relatively democratic institutional framework. One of the main challenges was to reconcile different quarreling factions and interest groups in an increasingly complex society. Extraordinary urban and industrial growth, the arrival of new players on the political scene, strong government intervention in the economy, some respect for the formal rules of democracy, an unprecedented mobilization of the working class, strong nationalism, and the growing politicization of social movements shaped and defined these years. Within this context, it became more and more difficult to govern without taking into account urban workers and their interests. Laborism (trabalbismo in Portuguese, from the name of the Brazilian Labor Party), created in the context of the end of World War II, had ties to this project aimed at preserving corporatist trade unionism during the transition to democracy. Such an objective was relatively successful in that, in general, between I945 and 1964, corporatist institutions coexisted with a democratic regime.

In those years, the institution of collective dispute resolution in Brazil was not incompatible with the right to strike and the exercise of that right, or even with direct action by unions or the workers. Many times, disputes were submitted to the regional tribunals before a strike was declared, but work stoppages not authorized by the Labor Court also frequently occurred, and sessions in the tribunals were extended until late at night in an attempt to conclude or avoid strikes. ${ }^{77}$ The combination of direct negotiation and legal action, as a part of the union strategy to confront dramatic alterations in the work process, was not uncommon, as occurred, for example, in the I950s with the workers of the Companhia Siderúrgica Nacional (National Ironworks Company) in Volta Redonda 
(Rio de Janeiro). ${ }^{7}$ The extensive research of José Sérgio Leite Lopes on the workers of the Companhia Paulista de Tecelagem (Paulista Textile Industry), in the state of Pernambuco in the north-east of Brazil, showed that the eclosion of strike movements and action in the Labor Court were complementary practices.

The massive recourse of the workers to the tribunals contributed to "consolidating the security of the very legitimacy of the workers' demands" as well as for the "organization and collective pressure in defense of those demands". ${ }^{79}$ The historian Murilo Leal revealed that from I 945 to 1964 seven in twelve salary campaigns of the metalworkers' union in São Paulo were accompanied by strikes (four of them "general”); among the textile workers, five in twelve campaigns counted with work stoppage movements, all of them "general". ${ }^{\circ}$ In 1953, the year of the famous "Strike of 300 Thousand", which practically paralyzed the city of São Paulo in March and April, seventy-two collective disputes were registered in the General Procuracy of the Labor Court. ${ }^{8 \mathrm{I}}$ There were even various work "paralyzations", such as in the immediate postwar years, in which many categories skipped the mediation of the Labor Court, overcoming the limits imposed by corporatism. ${ }^{82}$

Regarding the actions of the Labor Court as a normative instance of salary increases, the principal item in collective disputes, it has already been affirmed that judicial arbitration transformed negotiation and the signing of collective contracts, in some conjunctures, "into genuine rituals, free from any economic significance for the workers". ${ }_{3}^{3}$ Nonetheless, in widely documented research centered on collective conflicts between 1953 and 1964, the historian Larissa Corrêa revealed much more complex "rituals".

An important focus of conflict throughout this period revolved around the increase in the cost of living index, and subsequently, on salaries. In diverse salary campaigns and mass strikes, such as the "Strike of 400 Thousand" in October 1957, and the "Strike of 700 Thousand" in September 1963, both of

\footnotetext{
78. Oliver Dinius, "Brazilian Labor Courts and Industrial Relations under State Capitalism”, paper presented at the European Social Science History Conference (Lisbon, 29 February 2008).

79. José Sérgio Leite Lopes, A tecelagem dos conflitos de classe na "cidade das chaminés" (São Paulo, i 988), p. 366.

80. Murilo Leal Pereira Neto, “A reinvenção do trabalhismo no 'vulcão do inferno': um estudo sobre metalúrgicos e têxteis de São Paulo. A fábrica, o bairro, o sindicato e a política (1950-1964)" (unpublished Ph.D. thesis, Universidade de São Paulo, 2006), p. I 57.

81. Corrêa, Trabalhadores têxteis e metalúrgicos, p. 56.

82. Hélio da Costa, Em busca da memória: comissão de fábrica, partido e sindicato no pósguerra (São Paulo, 1995).

83. Armando Boito Junior, $O$ sindicalismo de Estado no Brasil: uma análise crítica da estrutura sindical (São Paulo, I991), p. 49.
} 
which occurred in the city of São Paulo, the tribunals, after the initiation of the disputes, felt the strong pressure of the workers' movement, with raucous demonstrations at their doors. On the occasion of the first strike, the judge Helio Guimarães, perhaps astonished, registered that: "in an epoch of agitation determined by the increase in the cost of living, by political passions, by agitators of all orders and kind, even the cost of living indexes suffered, in our view, by the influence of the groups in shock". According to him, "we are faced with the so-called phenomenon [...] of the pressure of groups on the execution of government policy. This because each part furnishes a certificate with the cost of living that suits them." ${ }^{84}$

Therefore, to judge the question of equity did not mean submitting the judges to the fixed rules of the political economy of diverse governments. On the contrary, the principle of equity brought with it ambivalence in such a way that, according to the jurist Luiz Roberto Puech, it constituted "notably subjective criteria through which the judge (in forming his conviction) does not restrict himself to rigid rules". ${ }^{5}$ A judgment based on the "social interest" could benefit the bosses as much as the workers, or generate "a duality of solutions" such that the arbitration sentence included appeals, opening up in this way disputes among the very judges at different judicial instances, such as occurred in the "Strike of 400 Thousand" in $1957 .{ }^{86}$

We are not faced, therefore, with a ritual in which all actions were defined beforehand. In fact, for union leaders and lawyers it was fundamental to know which judge would preside over a process, since the "profile" of the magistrate strongly influenced the terms of the sentence. ${ }^{87}$ Depending on the situation, different pressures and maneuvers were launched to confuse and complicate judgments which could be contrary to the workers' interests. In the words of one union leader, Afonso Delellis, it was necessary "to create such a jumbled situation that the solution could not be delivered in a sentence [contrary to the interests of the workers]". According to him, negotiations between parties in the Regional Office of Labor was a truly bureaucratic ritual, but that on the occasion of the "Strike of 700 Thousand", this was broken when "the bosses sat at the table and had a surprise: instead of encountering the directory of the workers' union, they were presented with representatives of the General Command of Workers (CGT)", an inter-union entity with a horizontal character, prohibited by law, but which had a great uniting role on social movements at the beginning of the $1960 .^{88}$

84. Cited in Luiz Roberto de Rezende Puech, Direito individual e coletivo do trabalho (São Paulo, I960), pp. 387-388.

85. Ibid., p. 390.

86. Ibid.

87. Correa, Trabalhadores têxteis e metalúrgicos, p. I25.

88. Ibid., p. I49. 
So the Labor Court did not invariably side with big business; its judgments sometimes went against employers, even in economic circumstances unfavorable to workers. ${ }^{89}$ Yet justice was not achieved without a fight for rights. The laws and labor-court system were an arena for legitimately demanding and securing broader rights brought about by workers' actions against their employers' arbitrary power, little by little modifying the original meaning of corporatism and of the control and cooptation of the working class. Institutional channels only really worked when there was mobilization, collective organization, and pressure from the working class..$^{\circ}$

As a demonstration of this, we may note that indignant and critical statements by employers and government officials after the inauguration of the dictatorial regime in 1964 underline that previously the tribunals had not made judgments according to the "public interest", since "the Labor Court persisted in the practice of conceding adjustments on the basis of a rising index in the cost of living, and, in some cases, even on superior bases". ${ }^{\mathrm{I}}$ In fact, the normative power of the tribunals was visibly favorable to workers in collective disputes in the months that preceded the military coup in March 1964. From June to November 1963, in a context of many strike actions and an accentuated political polarization between those who defended "structural reform" programs for the country and those who demanded a radical alteration of the constitutional order, of the 94 processes that were judged in the Regional Tribunal of Labor in the state of São Paulo, the majority for a salary increase, 7I per cent of the judgments were in some way favorable to the workers. ${ }^{92}$

It was exactly for this reason that the criteria utilized by the tribunals to verify the indexes of salary increases displeased the formulators of the various decrees that, during the military regime, resulted in a draconian "salary freeze" and a straightjacket on the normative power of the Labor Court. After 1964, adjustments had to be literally secured from formulas emanating from the executive, such that the labor tribunals, according to some records, no longer exercised any influence on salary calculations, thereby transforming collective bargaining into a fraud..$^{93}$ It was for this

89. Fernando T. da Silva, A carga e a culpa. Os operários das docas de Santos: direitos e cultura de solidariedade, 1937-1968 (São Paulo, I995); Jairo Q. Pacheco, "Guerra na fábrica: o cotidiano operário fabril durante a Segunda Guerra. O Caso de Juiz de Fora-MG” (M.A. thesis, Universidade de São Paulo, I996).

90. Alexandre Fortes, "Revendo a legalização dos sindicatos: metalúrgicos de Porto Alegre, 193 I-1945", in Alexandre Fortes et al. (eds), Na luta por direitos. Estudos recentes em história social do trabalho (Campinas, 1999), pp. 19-49.

91. Sitrângulo, O conteúdo dos dissídios coletivos, p. 35 .

92. This is the result of a research project that I have been developing, with the participation of Samuel Souza and Pedro Bortoto.

93. Mericle, Corporatist Control, p. 329. 
reason that in 1975 the jurist Rezende Puech emphasized: "with the prohibition of the strike [...] after the Revolution of 1964 - which, inclusively, created the compulsory calculation of foundations for salary increases - it became necessary to reinstate the normative power on just terms". ${ }^{94}$

In relation to this period, one can see a Labor Court in Brazil which was much more closely aligned with the objectives for which the Italian Labor Court was created. Without any doubt, both were never more similar in their intention to maintain "the superior interests of production and the nation". On the other hand, in observing individual rights in the I970s, the rate of increase in gaining such rights by way of jurisprudence was 80 per cent, showing that in the period of dictatorship the Labor Court represented one of the few spaces in which workers could have their rights recognized. ${ }^{95}$

In sum, the unfolding of normative power is less related to the "DNA" of the origins of these labor-law systems, and much more related to variables such as political regime, degree of organization and mobilization of the workers, the academic formation of the "operators" of the law, the juridicalpolitical conceptions of the magistrates, the weight of jurisprudence, the conflicts of interest and differences within the judiciary, the specific factors of the economic situation, and the relations of force between social and political agents. The period which followed the military dictatorship is illustrative of some of these points.

Between the end of the I970s and the beginning of the following decade, hundreds of strikes showed enormous dissatisfaction with the government, challenged the military regime, and put workers at the forefront of the struggle for re-democratization. This movement sparked the "new unionism", a current that, among other things, fought for the end of the corporatist union structure and for free collective bargaining against the interference of the Labor Court.

The new unionism strongly questioned the instrument of normative power since it was seen as a threat to the strongest unions, who, through direct negotiations, could obtain greater success without the risk of confronting the long appeals of the bosses to the justice system. To strengthen the bargaining power of the workers, the leaders of the new unionism advocated a new system of work relations, above all in the context of the Constituent Congress of I988. As a result of strong popular pressure, the Constitution, promulgated that year, promoted favorable changes for workers. Among the principal achievements was the extension of legal protection, the reduction of the working week to forty-four

94. Citado Sitrângulo, O conteúdo dos dissídios coletivos, p. 30.

95. Adalberto Cardoso and Telma Lage, "Desenho legal e desempenho real: Brasil", in Graciela Besunsán (ed.), Instituições trabalhistas na América Latina (Rio de Janeiro, 2006), pp. I6I-224, I 83 . 
hours, the unionization of public servants, greater union freedoms, and the right to strike. As much as these democratic advances were important, on the other hand, union structures remained practically intact, conserving, for example, the monopoly of legally instituted representation and the intervention of the Labor Court in individual and collective disputes. ${ }^{96}$

In practice, the Labor Court as much as the unions was putting the normative power in second place, prioritizing free negotiation between the parties. Yet if in the I 980 s unionized workers, above all those affiliated to the strongest representative entities, were successful in winning rights, the I990s witnessed more losses than gains in collective negotiations. For the union movement, the last decade of the twentieth century was an era of the flexibilization of rights, productive restructuring of companies, and neoliberal cutback policies, which resulted in unemployment and reduction in the number of strikes and union density as well as concessions in collective contracts. Moreover, the proliferation of thousands of unions, favored by the Constitution itself, and negotiations with individual employers were responsible for the enormous destruction of collective agreements and labor contracts. ${ }^{97}$ Confronted with this disaggregating scenario, the new unionism shifted from "confrontation to conflictual cooperation", and from refusal to a certain accommodation with the existing labor relations structure..$^{98}$

Furthermore, direct negotiation between labor and capital no longer appeared as a panacea. In the words of a militant of new unionism, it is "impossible to speak of free negotiation in the face of the unbalance between the contractual parties. Exactly because of this, the constitutional norm and the law, as basic guarantees, are so necessary and fundamental."99 Above all, for the less organized workers and for those with less bargaining power, the Labor Court signified a space for the protection of rights and its

96. Armando Boito Junior, O sindicalismo de Estado no Brasil; Marcio Pochmann, "Mudança e continuidade na organização sindical brasileira no período recente", in Carlos A. Oliveira and Jorge E. Mattoso (eds), Crise e trabalho no Brasil (São Paulo, 1996), pp. 269-301; Iram J. Rodrigues, “A trajetória do Novo Sindicalismo", in idem (ed.), O novo sindicalismo (Petrópolis, 1999), pp. 73-94; Antônio Cruz, A janela estilhaçada: a crise do discurso do novo sindicalismo (Petrópolis, 2000); Carlos A. Oliveira, "Contrato Coletivo e Relações de Trabalho no Brasil", in Oliveira et al., O mundo o trabalho, pp. 209-232.

97. Marcio Pochmann, “Adeus à CLT? O 'eterno' sistema corporativo de relações de trabalho no Brasil”, Novos Estudos CEBRAP, 50 (1998), pp. I49-165; Adalberto M. Cardoso and Telma Lage (eds), As normas e os fatos; Francisco. L. Gonçalves, "A evolução dos acordos e conflitos no período recente do sindicalismo brasileiro (1977-1993)", in Oliveira et al., O mundo o trabalho, pp. 267-287.

98. Iram J. Rodrigues, "O Sindicalismo Brasileiro: da confrontação à cooperação conflitiva”, São Paulo em perspectiva, 9 (1995), pp. I I6-I 26; Giovanni Alves, "Do 'Novo Sindicalismo' à 'Concertação Social'”, Revista de Sociologia e Política, is (2000), pp. I I I-I 24.

99. Edésio Passos, “Os direitos dos Trabalhadores”, in José Inácio, Sindicalismo no Brasil (Belo Horizonte, 2007), pp. I83-2 I I, 200. 
maintenance was demanded as a principal arbiter in labor conflicts. ${ }^{100}$ As for individual rights, according to recent research in the I990s, the judicial system fulfilled "its function as guardian of labor rights", becoming the "most important organ in the defense of labor rights". The probability of workers in Rio de Janeiro, for example, seeing their demands met between I 995 and 2000, oscillated between 50 per cent and 80 per cent. ${ }^{\text {IOI }}$ In Campinas, between 1987 and 1990, 86 per cent of workers had their grievances resolved in some way or another. ${ }^{102}$

It is revealing that in public opinion the Labor Court enjoys much more legitimacy than the ordinary courts. According to research from 1997 among workers who had occasion to resort to both types of courts, on a scale of I to IO, the Labor Court, got a mark of 6.7 and the ordinary courts, 4.4, since it was in the Labor Court that workers saw that they had a chance to be victorious in legal conflicts. ${ }^{\mathrm{IO} 3}$ We can therefore see that the evaluation of the performance of the Labor Court extrapolates the limits of academic debate.

\section{LEGISLATIVE MODEL AND THE GHOSTS OF CORPORATISM}

The grave problem of the vast academic and juridical tradition in Brazil is that it has accepted in the last instance the high-sounding declarations of the formulators of corporatism. ${ }^{104}$ On this view, the corporatism of the New State had a much less integrative, or communitarian, character in the mold designed by Oliveira Vianna, and much more of a repressive and exclusive nature, excessively limiting trade-union action. What prevailed was control of the unions, the conception that strikes were illegitimate and "anti-social", and that the state maintained the right to "anticipate" the demands of the workers. ${ }^{\text {IOS }}$ However, a number of empirically rich studies have revealed a history in which the state is no longer the "alpha-omega" of the experience of the workers. And the contrast with the idealized models of the workers' movement in the countries where capitalism arose, which has caused such an inferiority complex among many Brazilian intellectuals, is no longer the parameter of recent historiography.

What we are still lacking are refined comparisons between the legislative model of labor relations, such as in Brazil, in which the laws were an

ı०o. Elina G. Pessanha and Regina L. Morel, "Mudanças recentes no modelo de relações de trabalho no Brasil", in Rodrigues, O novo sindicalismo, pp. 95-I I 2.

ıо . Adalberto Cardoso and Telma Lage, "Desenho legal e desempenho real", p. 2 I 2.

102. Paulo A. Setti, Merecimento e eficiência: performance de advogados e juízes na Justiça do Trabalho em Campinas (Campinas, 1997), p. 22.

I03. Mário Grynspan, "Acesso e recurso à justiça Brasil: algumas questões”, in Dulci Pandolfi et al. (eds), Justiça e violência (Rio de Janeiro, I999), pp. 99-I I 3.

104. Hall, "Labor and the Law in Brazil", p. 89.

ı०5. Cardoso, "Direito do trabalho e relações de classe no Brasil". 
instrument of greater relevance in the fixation of rights, and the negotiated model of countries with a contractualist tradition, in which rights were defined by collective agreements. ${ }^{106}$ The efforts of Tâmara Lothian, for example, in comparing Brazilian corporatism and American contractualism has been practically ignored in debates in the Brazilian literature. Lothian's conclusion that countries with corporative labor regimes have a "more vigorous, independent and politicized labor movement" will probably perplex those unconditional adepts of the primacy of negotiation over legislation. ${ }^{107}$ Certainly, such a conclusion is polemical and deserves more careful examination. ${ }^{\text {.0 }}$

We need however, to evaluate the corporatism implanted by Getúlio Vargas in all its ambiguity: as an authoritarian project with clear fascist inspiration as well as an institutional arrangement that, in practice, did not eliminate the mobilization and organization of the workers nor close itself to the representation of various interests. ${ }^{109}$ As Lothian lucidly observed, in the hands of a regime of force, the corporatist system could be a strong ally of the politics of repression and cooptation. On the other hand, in more open contexts, it could also convert itself into an instrument of union militancy and organization, the politicization of the workers' movement, the radicalization of social and political policies, pressure on the government in favor of pro-worker measures and pluralist competition between different ideological and political factions. ${ }^{\text {II }}$

A comparison between different juridical labor systems thus could be more fertile if we explore the problem with less weight attributed to corporatism and more on the nature of the legislative model that could exist within a corporatist system or not. ${ }^{\text {II }}$ As we have seen, legislation

106. Eduardo Noronha, Entre a lei e a arbitrariedade: mercado e relaçôes de trabalho no Brasil (São Paulo, I999), p. I 2.

I07. Tâmara Lothian, "The Political Consequences of Labor Law Regimes: The Contractualist and Corporatist Models Compared", Cardozo Law Review, 7 (1986), pp. I001-1073, 1003.

I08. See the polemics between Lothian and Stanley Arthur Gacek; Tâmara Lothian, "Reinventing Labor Law: a Rejoinder", Cardozo Law Review, I6 (1995), pp. 1749-1763; Stanley Gacek, Sistemas de relações de trabalho: exame dos modelos Brasil-Estados Unidos (São Paulo, 1994).

I09. Renato R. Boschi and Maria Regina de Lima, "O executivo e a construção do Estado no Brasil: do desmonte da Era Vargas ao novo intervencionismo regulatório", in Vianna, $A$ democracia e os três poderes no Brasil, pp. 195-253.

I I0. Lothian, "Political Consequences". In the last twenty years, a vast academic production has revealed the contradictions of corporatism in Brazil and the forms by which workers led creatively the institutions created in the post-1930 period. For a historiographical survey, see Fernando T. Silva and Hélio da Costa, "Trabalhadores urbanos e populismo: um balanço dos estudos recentes", in Jorge Ferreira (ed.), O populismo e sua história. Debate e crítica (Rio de Janeiro: 200I), pp. 205-27I.

I I I. Philippe Schmitter had already made this warning in "Still the Century of Corporatism?", in Fredrick B. Pike and Thomas Stritch (eds), The New Corporatism: Social-Political Structures in the Iberian World (London, 1974), pp. 85-131. 
and arbitration of labor are instruments of constant state regulation in various non-corporatist countries.

It is probable that normative power had inhibited the practice of the collective negotiation so frequent in contractualist models. Nevertheless, the impact of the content of judicial decisions regarding collective negotiations still lacks thorough studies in Brazil. ${ }^{I 2}$ We can presume as well as that the difficulties of implanting in Brazil a tradition of direct negotiation between employers and workers should not be reduced to the normative power of the tribunals, but also to other factors such as the existence of abundant and detailed legislation that in a way became "the Brazilian equivalent of private collective contracts". ${ }^{13}$ It is also worthwhile adding the fact of the traditional refusal of employers to begin negotiations.

Since the I990s, on the other hand, contrary to the explosion of litigiousness witnessed in individual disputes, there has been a decrease in the number of collective disputes brought to the Labor Court and an increase in direct collective agreements. ${ }^{I I 4}$ In any case, it is still too early to appraise the effects of the promulgation of Constitutional Amendment n.45 of 8 December 2004 which limits the exercise of normative power. Without doubt, however, we are quickly moving from "state corporatism" to a pluralist legislative system. ${ }^{115}$ Yet the increase of individual processes in the justice system and the weakening of union activity have appeared to debilitate collective actions and negotiations. For this reason, the challenge has been to avoid the employers taking the initiative and controlling the "normative" decision. There is also the question of strengthening the Labor Court as an instrument of struggle for rights and social mobilization. In the moment of the explosion of litigiousness in individual disputes and the reflux of collective conflicts, the question is to know how to "collectivize" labor law without limiting the judicial arena to a merely defensive space. ${ }^{116}$

\section{“INCLINATION FOR FASCISM" AND OTHER SOURCES OF LAW}

There still remains to be undertaken a detailed study about how the actual transfer of ideas on labor law from Italy and other countries took place in practice in Brazil. But Oliveira Vianna has given us some interesting hints.

I I 2. Carlos Henrique Horn, "Negociações coletivas e o poder normativo da Justiça do Trabalho", Dados, 49 (2006), pp. 417-445.

I 1 3. Hall, "Corporativismo e fascismo", p. 24.

I I 4. Pinto, I00 anos de sindicalismo, pp. 234-237.

i I 5 . Noronha, Entre a lei e a arbitrariedade, pp. 49-53.

I 16. Regarding the perspective of transforming union organizations into co-producers of the law, searching to collectivize individual causes and intervene directly in judicial activity; see Willemez, Le droit du travail en danger. 
As much as he insisted that labor laws in Brazil were not a copy of the Workers' Charter in Italy, he recognized the "inclination to fascism" on the part of "technical officials" encumbered with the task of elaborating trade-union and labor legislation who were familiar with the "Italian treaty writers of Social and Corporatist Law". According to him,

Their works entered here in copious abundance; stacks and stacks of them accumulated in bookstore displays. There were even stores specializing in the material, such as the Boffoni Bookstore, which became a type of Mecca for all those interested in these new and fascinating topics. The volumes of Barassi, Zanobini, Costamagna, Cioff, Palopoli, Carnelutti and all the luminous constellation of jurists of Mussolini's corporatism arrived there and soon disappeared from the shelves, absorbed by the thirst for knowledge of the scholars of the new doctrine.

To remove any doubt about such an influence, Vianna added that "in the talks of technical officials and improvised specialists [...], the Italian language was spoken almost as much as Portuguese". ${ }^{117}$ But his writings, as he himself made a point of stressing, engaged with various other international experiences. In the debates around the organization of the Labor Court in I935, Vianna refuted the accusations regarding supposed fascist influences in the document and aligned himself with the principles of constitutional law in the United States, where, according to him, the Supreme Court recognized the constitutionality of delegations of normative power, making reference to the "regulatory agencies" and the "corporations" of the New Deal. ${ }^{\text {I18 }}$ A voracious reader of American jurists, Vianna believed that the decadence of liberal democracy was expressed in the path that the United States was taking towards corporatism. ${ }^{119}$ Indeed, during the New Deal there was active intervention of the government in the regulation of conflicts between capital and labor in the name of the construction of an "industrial democracy". In 1935, Congress approved the Wagner Act, creating an arbitration instrument, the National Labor Relations Board, the equivalent, in a way, of the labor courts in other countries. ${ }^{\text {I2O }}$ In Vianna's writings, there are also abundant rebuttals of French solidarism, something which also marked his intellectual production. ${ }^{\mathrm{I} 2 \mathrm{I}}$

Nonetheless, according to him, such "abundance of foreign citations" was a "comparative means, in the quality of information that has made itself felt or that exists among other peoples". ${ }^{22}$ To finalize, he made the

I 17. Oliveira Vianna, "Razões da originalidade do sistema sindical brasileiro", in idem, Ensaios inéditos (Campinas, 1991), pp. 277-281, 278-279.

I I8. Vianna, Problemas de direito corporativo, pp. 48-57.

I 19. Bresciani, O charme da ciência, pp. 422, 434-436, 439.

120. Nelson Lichtenstein, State of the Union: A Century of American labor (Princeton, NJ, 2002), pp. 36-37, 63 .

I2 I. Bresciani, O charme da ciência, ch. 6.

I22. Vianna, Problemas de direito sindical, p. xiv. 
following exhortation: "one who dedicates themselves to a comparative study in this way, will see that $[\ldots]$ there are many points, despite being secondary, that differentiate our social legislation from the social legislation of other peoples". ${ }^{123}$

On the one hand, the comparative effort in this text has aimed to show that, "on many points", the Brazilian and Italian Labor Courts were quite different, but also shared similarities. On the other, we should credit Vianna's nationalism for his repeated and resounding declarations about the originality of the union system and judicial structure of labor in Brazil. Following Vianna's exhortation that "one who dedicates themselves to comparative work" on the labor courts of various countries, will probably discover that no formal element of the structure of Brazilian labor law is completely original to Brazilian corporatism, we could extend the comparison to other nations, and we should see that there are many differences between labor tribunals in countries with similar political regimes as there are juridical similarities between countries with quite distinct forms of government. ${ }^{\mathrm{I} 4}$

If we observe, for example, the Conseils de Prud'hommes in France, where, since the beginning of the twentieth century, the state exercised a growing intervention in the world of work, we will discover that there, as in Brazil, there was an attempt to find a preliminary means of conciliation; that the French institutionalized typically judicial labor courts, legalized relations between employers and employees (due in part the fragility of collective negotiations), rooted themselves in the organization of the workers and the judicialization of their conflicts on local terms, and appealed to the tribunals as a form of filling the vacuum left by low levels of unionization since the courts and unions could defend the interests of even the unaffiliated. The hypothesis of Couton that the Conseils would have disappeared if corporatism, cooperative socialism, or contractualism based on free collective negotiation had taken hold in France remains suggestive. ${ }^{\text {I25 }}$ In Brazil as well, none of these presented themselves as solid alternatives.

If we turn our attention to Weimar Germany we will find a judicial organization of labor more similar to that of Brazil, despite the great difference of the autonomous union structure in Germany. Brazilian jurists such as Pontes de Miranda, Waldir Niemeyer, Evaristo de Moraes Filho, and Egon Gottschalk were greatly influenced by German labor law. ${ }^{\text {I26 }}$ The jurist

I23. Idem, Direito do trabalho e democracia social (São Paulo, I95 I), p. I4.

I24. Ralf Dahrendorf, As classes e seus conflitos na sociedade industrial (Brasília, 1982), translation of Class and Class Conflict in Industrial Society (London, 1972), p. 202.

I25. Couton, $A$ Labor of Laws.

I26. Regina Morel de Moraes et al. (eds), Sem medo da utopia: Evaristo de Moraes Filho: arquiteto da sociologia e do direito do trabalho no Brasil (São Paulo, 2007), pp. 50, 72; Gottschalk, Norma pública. The data from Germany are based on Wunderlich, German Labor Courts. 
Bezerra de Menezes testified that the Weimar Constitution, "that dedicated a section to economic life and contains various dispositives concerning the right to work", inspired the Brazilian formulators of the labor laws of $1933 .{ }^{127} \mathrm{In}$ Weimar, there was a justice system with a tripartite composition, contrary to France, and its functioning was much less formal than the common justice, with high levels of individual litigation, conciliation, and successful outcomes. The processual rite also demonstrated various similarities with the Brazilian Labor Court: the parties presented their arguments, the class representatives or lay judges were present in the audiences, and an agreement between litigants was initially tried, but the magisterial judge had the initiative and the power to structure the process, and in the end, exercised a greater influence in the judgment, since, as in Brazil, the class representatives had less power to intervene in the processes. ${ }^{\mathrm{I} 28}$

In organizational terms, the courts of first instance were independent of the common justice, functioning as a special justice, even though, as in Brazil, the judges were career magistrates. An even closer similarity to the Brazilian case can be seen, as already demonstrated, in the composition and election of the members of local and secondary courts, both represented by career magistrates and lay judges chosen from a list of candidates prepared by the union and the employers' associations. Weimar also adopted a tripartite system of justice in local and regional tribunals (which functioned as an appellate court, such as the regional tribunals in Brazil) and a Federal Labor Court. Perhaps for this reason, historiographical criticisms have also arisen in Germany that the labor courts had coopted the workers' representatives, who were seen as state agents, ${ }^{\text {I29 }}$ in a similar way to the Brazilian sociological tradition.

Looking at the footnotes of the books of various jurists cited in this article, the majority of whom were specialists in international comparative law, we can find numerous references to labor legislation and courts in other countries, with abundant and erudite citations of works published in diverse foreign languages. But is not possible here to multiply the international comparisons since, as with the similarities, we can also point to profound differences. It is still necessary to study much more thoroughly the subject of the supposed peculiarity of the Brazilian Labor Court.

I have argued that the presupposition that the Labor Court was a copy of the Italian is a fallacy, principally because the comparison should not only treat the formal institutional aspects of the two countries. Brazil still lacks a wide study of the Labor Court, similar to that of Jian Carlo Jocteau, who thoroughly analyzed the functioning of the Italian Labor

I27. Geraldo B. de Menezes, Dissídios coletivos, p. 3 I.

I 28. Blankenburg and Rogowski, "German Labour Courts", p. 83.

I29. Aaron, "The NLRB", p. 44. 
Court in the fascist period, its doctrinaire formulations, the action of the "operators" of justice, its processes of individual and collective disputes, the position of the workers, bosses, and unions in relation to judicial decisions, the different visions regarding the efficacy and legitimacy of the tribunals and, principally, the complex articulations between the judicial system and the fascist government. The broad range of perspectives allowed the author to conclude, in a few words, what I have tried to affirm here about the Italian Labor Court:

The abolition of "private" representatives of the parties in the adjudicating instances; the presence of employers' representatives in its interior; the accentuation of the elements of control by the executive and the top judiciary; unification of jurisdiction: these are the salient traces of fascist reform in the field of labor relations, which attributed to the new "special" sections and constituted together with the ordinary magistrature an indispensable institutional role in the discipline of social conflict. ${ }^{\mathrm{I} 3}$

This restrictive experience for Italian workers must explain why in 1948 the submission of collective conflicts to compulsory arbitration was ended, since it was an institution considered contradictory to the principles of collective bargaining even though it was largely useless during the fascist regime. ${ }^{1{ }^{1}}$ Yet the longevity of the Brazilian Labor Court, which suffered few alterations in the many decades since its incorporation in the judicial power in 1946, is perhaps one of the signs that the experiences of justice in the two countries were so different. The origins of the labor tribunals in Brazil remain, without doubt, in the authoritarian terrain of Vargas corporatism, but at the same time their institutional arrangement seems to have been flexible and adaptable to different political periods, becoming, in practice, an arena of conflicts and representations of interests, as well as a space in which the law was subject to different interpretations and appropriations between the representatives of the workers and employers.

Whatever the relation is between the legislative model and the weak tradition of direct negotiation between workers and employers in Brazil, the judicialization of work relations became a strong formative element of the Brazilian working class. The confrontations in the labor courts also influenced the working class in a discursive aspect, constituting a "narrative of rights and laws". The "institutionalization" of class conflict did not indicate that there was no strong pressure from the workers' movement in some conjunctures, transforming the perception that the Labor Court was a mere intermediary organization, neutral or autonomous in relation to social classes. The analyses of the reactions of bosses and

I 30. Jocteau, La magistratura e $i$ conflitti di lavoro, p. Io9.

I 3 I. Gino Giugni, "The Settlement of Labor Disputes in Italy"; Aaron, "Labor Courts", p. 257. 
employees to judicial decisions have shown that the tribunals transformed themselves into institutions with access to social and political rights, forcing the diverse actors to strengthen and to modify the institutional bases of the regulating power of labor conflicts. ${ }^{132}$ Throughout its history, different government and political regimes have adhered to the Labor Court, as a "paternalist" model and restrictive force for union rights and as an institution inclusive and representative of the world of work. Therefore, we are confronted with juridical-political mechanisms that have been associated at the same time with subordination, tutelage, and collective appropriation.

If the Italian fascist regime, in practice, did not really take seriously the corporatist state, at least in its original integrative models, we have still more reason to suspect the implacable force of corporatism in Brazil. ${ }^{\mathrm{I} 33}$ Writing in 1944 "against certain conceptions of Italian corporative law" and against the equation, corporatism = fascism, the jurist Egon Feliz Gottschalk had already shrewdly observed that "corporatist organization, however, is still not definitive in Brazil". And he followed this up by affirming that the confrontation between Italian and Brazilian corporatism "does not oblige us to accept it as any more than a mere inspiration". ${ }^{\mathrm{I}} 34$

However, this affirmation is certainly less valuable for the corporatist union order as a whole and more for the Labor Court in Brazil, in particular. There is no doubt that the role for which the Labor Court was conceived in the Brazilian corporatist edifice was similar to the role of the Labor Court in the Italian corporatist arrangement. Yet the assembly of its parts and its functioning were different in diverse aspects. This resulted in the first place from a wider international repertory of congeneric experiences known by Brazilian jurists and legislators. Second, many of the characteristics of the Labor Court in Brazil were already rooted in similar institutions implanted in the country from the I920s, which generated practices, doctrines, and jurisprudence that influenced the construction of the judicial system during the New State. ${ }^{\mathrm{I}} 35$ Third, corporatism survived the Vargas dictatorship, after which its components, such as the Labor Court, were adapted and appropriated by the workers for ends that were not identical with those for which they were created.

\footnotetext{
132. For a brief survey of this production, see Fernando Teixeira da Silva, "Nem crematório de fontes, nem museu de curiosidades: por que preservar os documentos da Justiça do Trabalho", in Magda Barros et al. (eds), Memória e preservação de documentos: direitos do cidadão (São Paulo, 2007), pp. 3 I-5I.

133. Hall, "Labor and Law in Brazil", p. 89.

134. Gottschalk, Norma pública, pp. I2, I6, 38 .

I35. Souza, "Coagidos ou subordinados': trabalhadores, sindicatos"; Magda Biavaschi, O direito do trabalho no Brasil, 1930-1942 (São Paulo, 2007).
} 


\section{FINAL CONSIDERATIONS}

In conclusion, the comparative method demands more than simply knowing the law and juridical structures of different countries. It is necessary, above all, to consider the contexts in which both were produced. ${ }^{136}$ Without doubt, it is a matter of analyzing the constitution and functioning of the tribunals, focusing on the doctrinaire formulations and the laws which formed the base of their actions. On the other hand, one must also investigate the interpretations that the "operators of the law" (lawyers, class representatives, judges) and the parties in disputes made of the legislation and the Labor Court. In this way, we can avoid both the formalist and internalist interpretations of the law, seen as a largely autonomous sphere, and the instrumentalist conception which sees the Labor Court as purely an apparatus of domination by the state and employers. ${ }^{\mathrm{I}}{ }^{37}$

To understand the Labor Court as a cynical and individualist expression of class interests or as a "court of the workers", an implacable restorer of usurped rights, is a form of fixing a false antinomy, always present respectively among the defenders of the Labor Court as a reproduction of the fascist model and the those who consider it a product "made in Brazil". ${ }^{1{ }^{8}}$ It would be more helpful to understand the law as an arena of conflict and negotiation in different historical contexts. Consequently, it is necessary to make an inventory of the situations and expectations that motivated workers, employers, and unions in Brazil, in Italy, and other countries, to mobilize around the labor courts, confronting and challenging the apparent rigidness of the laws and the juridical field.

I 36. R. Blanpain, "Comparativism in Labour Law and Industrial Relations", in idem (ed.), Comparative Labour Law and Industrial Relations in Industrialised Market Economies (Deventer, 2004), pp. 3-24.

I37. Pierre Bourdieu, "A força do direito: elementos para uma sociologia do campo jurídico", in idem, O poder simbólico (Rio de Janeiro, 2007), pp. 209-254.

138. Regarding this false antinomy, see Peter Linebaugh. The London Hanged: Crime and Civil Society in the Eighteenth Century (Cambridge, 1992), pp. xxii, xxiii. 